\title{
Giftulykken i Simmersted
}

Af Leif Hansen Nielsen

Natten mellem den 20. og 21. januar 1972 klokken ca. 23.30 forulykkede en tankvogn i den lille landsby Simmersted ti km nordvest for Haderslev i Sønderjylland. Det var for så vidt et banalt uheld, men omstændighederne gjorde, at netop dette uheld fik afgørende betydning for miljøpolitikken i Danmark. Det var landets første større forureningsulykke. I denne artikel undersøges det, hvordan dette uheld kunne udvikle sig til en kæmpe forureningskatastrofe. Fokus er rettet mod det umiddelbare beredskab, men også på følgerne af forureningen samt de økonomiske og politiske konsekvenser.

\section{Indledning}

Gennem alle tider har mennesket været afhængig af naturen og de muligheder, den kunne tilbyde. Efter industrialiseringens gennembrud i det 19. århundrede, og særligt i det 20. århundrede med den teknologiske og kemiske udvikling, er der sket et paradigmeskifte, så naturen nu også er blevet afhængig af menneskets handlinger. Hvor forurening tidligere primært drejede sig om direkte uhygiejniske, ofte lokalt afgrænsede, sundhedsskadelige forhold som røg, støj, affald, fækalier og spildevand, kom det nu også til at handle om, hvorvidt naturen/ miljøet overhovedet kunne bære den kemiske forurening. Et væsentligt forhold i dette paradigmeskifte var hele den ændring i synet på økologi, økonomi og produktion, der gjorde sig gældende fra starten af 1960'erne og frem, nationalt såvel som internationalt. I Danmark så NOAH, landets første egentlige miljøorganisation, således dagens lys i marts 1969. Paradigmeskiftet blev dog også hjulpet på vej af flere uforudsete forureningskatastrofer som f.eks. Simmersted-ulykken i 1972.

Den historiske udvikling inden for forureningsbekæmpelse er kun sparsomt behandlet i den eksisterende forskning. Fremhæves skal dog Jens Engbergs banebrydende bog, "Det heles vel", fra 1999, hvor forureningsbekæmpelsens historie i Danmark behandles fra vedtagelsen af loven om sundhedsvedtægterne i 1850'erne og frem til miljøloven i 1974. Tidligere, i 1980, har Claes Nue behandlet tilblivelsen af miljøbeskyttelsesloven i Retfærd, no. 15 (Modtryk). De fleste indlæg vedrørende miljøbeskyttelse har imidlertid bestået af debatindlæg, cases eller undersøgelser som f.eks. Thorkild Bjørnvigs "Hvalerne har sange 


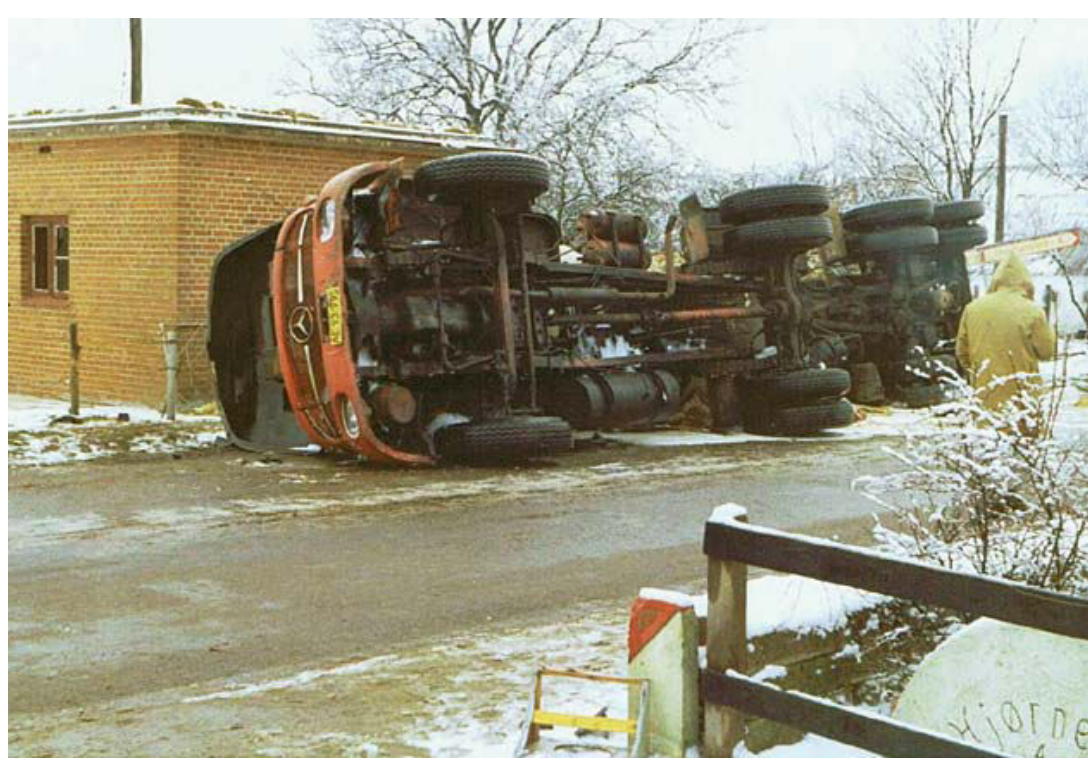

Som en strandet hval lå den forulykkede tankbil inde midt i Simmersted by - ganske tæt ved byens vandværk. Foto: Lokalhistorisk arkiv for Vojens-området.

og naturen har rettigheder. Om nødvendigheden af en økologisk socialisme" (Vindrosen 4, 1972); NOAH's publikationer, eksemplificeret med f.eks. "Atomaffaldsdeponering i etisk perspektiv" fra 2014; Mikael Skou Andersens "Miljøbeskyttelse - et implementeringsproblem?" i Politica 1989 eller Jesper Holm, Bente Kjærgård og Kåre Pedersen (red.): "Miljøregulering - tværfaglige studier" fra 1997.

I forhold til denne artikels primære emne, giftulykken i Simmersted, er litteraturen i særdeleshed beskeden. Bortset fra enkelte indlæg på nettet, f.eks. tidligere brandinspektør H.E. Høyer's beretning på www. simmersted.dk, er ulykken kun behandlet af Rasmus Dahlberg i bogen "Danske katastrofer" fra 2014.

Kildematerialet til nærværende fremstilling skal derfor findes i de lokale myndigheders arkiver, særligt hos kriminalpolitiet i Haderslev, der har en stor og fyldig sag om fenolulykken. Den indeholder både politirapporter, vidneforklaringer, domme, opmålinger med meget mere. Derudover er benyttet materiale fra Justitsministeriet, som bl.a. indeholder myndighedernes overvejelser vedrørende erstatningsspørgsmålet. Desuden er der benyttet materiale fra retten i Kolding, fra Folketingstidende og fra Folketingets forhandlinger. Endelig er der gjort flittigt brug af diverse aviser, hvoraf en del er bevaret i ovennævnte politisag.

Grundmaterialets officielle karakter har gjort det muligt at følge hændelsesforløbet ganske tæt, men kildernes tilblivelsessituation, henholdsvis en politisag, en retssag og en erstatningssag, sætter også rammer for benyttelsen; dels er oplysningerne ofte meget faktuelle, dels skal de impliceredes udsagn ses og vurderes ud fra den konkrete tilblivelsessituation.

\section{Ulykken i Simmersted}

Lidt før midnat, i mørke, dis, med temperaturer omkring frysepunktet og med snesjap på vejen, nærmede en Mercedes Benz sættevogn sig Simmersted nordfra ad Østerskovvej. Lasten var 23 tons flydende, $80^{\circ}$ varmt, fenol. Et stof, der ved almindelig stuetemperatur er i fast form og nærmest harmløst, men som i flydende form afgiver giftige dampe og er stærkt ætsende. Opløst i vand, selv i meget små mængder, er fenol uhyre giftigt.

Vejen gik op over en lille bakke og ned mod T-krydset inde i Simmersted by. Chaufføren, Erik Nielsen, så krydset, tog farten af køretøjet med den såkaldte slingrebremse på sættevognen, slap den igen umiddelbart inden svinget, bremsede ned med forvognen og skiftede gear. I svinget slap han bremsen og lod forvognens motor trække rundt. Pludselig mærkede han et uventet skub fra venstre side bagfra og trådte i refleks på bremsen. Motorvognen skred ud, vogntoget rullede om på siden, kurede over og lagde sig op ad det lokale vandværk. ${ }^{1}$ Ulykken var sket.

Fortumlet kravlede chaufføren ud af førerhuset. Han bemærkede straks den kraftige lugt af fenol og løb op til et hus efter hjælp. Inden han her mistede bevidstheden, nåede han at fortælle, at der var farlig gift $i$ tanken, og at man skulle holde folk borte. Politi og ambulance blev tilkaldt. $^{2}$

Chaufføren, Erik Nielsen, havde kun været ansat som "udlandschauffør" i små tre måneder hos vognmand K. E. Kruse i Bramdrupdam, men han var en erfaren chauffør med mange år bag sig, bl.a. havde han en årrække virket som kørelærer. Han havde denne gang været fem dage undervejs og havde tilbagelagt en strækning på mellem 1.500 og 1.700 $\mathrm{km}$. Søndag aften var han kørt ud fra Bramdrupdam ned over grænsen med kurs mod et sted syd for Hamborg, hvor han hentede en last kemikalier, der blev fragtet til København via Gedser. Derfra gik turen 
til Ringsted efter animalsk fedtstof til margarineproduktion i Holland. Efter losning i Holland gik det atter sydover til Fenolchemie GmbH i Gladbeck ved Essen, hvor han hentede den skæbnesvangre last af fenol til Rockwools fabrik i Vamdrup. Inden han startede hjemover fra Gladbeck torsdag formiddag, havde han fået en god lang søvn på ca. 12 timer. Han holdt en times frokostpause omkring kl. 13, og da han nåede Flensborg hen på aftenen, holdt han atter en pause og spiste aftensmad. Omkring kl. 22.00 krydsede han grænsen og kørte mod Vamdrup. ${ }^{3}$

I den efterfølgende retssag fortalte chaufføren, at han på en rasteplads i Tyskland havde opdaget en lækage i tanken. Efter telefonisk kontakt med firmaet hjemme i Bramdrupdam blev det besluttet, at han skulle skynde sig hjem og få losset. Det var årsagen til, at han havde valgt at skyde genvej hen over Sommersted og Jels til Vamdrup. Han tog dog den forkerte vej i Haderslev og endte i Simmersted frem for i Sommersted. Det fremgik også af retssagen, at chaufføren ikke var bekendt med, at så tunge vogntog, som der her var tale om, ikke måtte benytte de små veje, han denne aften befandt sig på. Vogntog af denne størrelse skulle køre ad de såkaldte blå ruter, dvs. så vidt muligt ad hovedvejsnettet. Aktuelt skulle han være kørt til Kolding og derfra ned til Vamdrup. ${ }^{4}$

Efterfølgende viste det sig også, at vognen havde en del sikkerhedsmæssige mangler. Foruden manglende skiltning om vægt, var der heller ingen parkeringsbremse på sættevognen. Begge dele har dog næppe haft den store betydning i forhold til ulykken. Mere alvorligt var det imidlertid, at seks af sættevognens otte dæk var nedslidte, nogle endda ned til lærredet, og at de skvulpeplader, tanken oprindeligt havde været forsynet med for hver 3.000 liter, var fjernet, så der nu ved pludselige opbremsninger eller retningsskift kunne opstå "bølgegang" i tanken. ${ }^{5}$ Tanken var dimensioneret til 25.000 liter, men kørte denne nat med $23.000 \mathrm{~kg}$ fenol. Med en vægtfylde på 1,07 svarede det til 21.600 liter. Det var formentlig bevægelse i tanken, der fik chaufføren til intuitivt at trykke på bremsen i krydset i Simmersted.

\section{Nattens arbejde}

De første myndighedspersoner på stedet var den tilkaldte ambulance og en politipatrulje bestående af overbetjent J. Hansen og politibetjent Henry Olsen. Sidstnævnte fik talt med chaufføren inden han blev kørt bort til sygehuset. Atter fortalte chaufføren, at der var en farlig væske i tanken, og han fortalte også, at der lå en vejledning i førerhuset med ret-

ningslinjer for, hvorledes fenol skulle behandles i tilfælde af uheld. På grund af giftfaren holdt de to betjente sig fornuftigt nok på afstand fra vogntoget, ligesom de forbød nysgerrige at gå tæt på vognen. Hurtigt var også Sommersted Frivillige Brandværn blevet tilkaldt med tre køretøjer, ligesom Vojens Kommunale Brandvæsen under ledelse af brandinspektør og civilforsvarsleder Hans Erik Høyer med røgdykkerudstyr. ${ }^{6}$

I den følgende times tid accelererede begivenhederne med etablering af afspærring, tilkaldelse af forstærkning fra Falck-Zonen og CFkolonnen i Haderslev - også med røgdykkere - samt CF-kolonnen i Middelfart med kulsyreapparater til nedkøling af den giftige væske.

\section{Phenolchemie GmbH} 439 GLADBECK i. W.

\section{Unfallmerkblatt für Tankwagen}

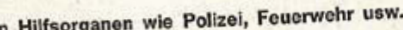
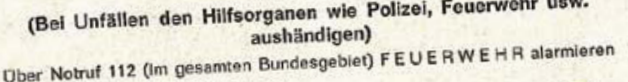

Ober Notrut Ni2

Tantwagen Nr.7.E.93.995 Datum 20.1.72

Ladung: Phenol, tlussig mil $\mathrm{Ca} .80^{\circ} \mathrm{C}$

a) Art der Gefahr

Brennbar, Flammpunkt $79^{\circ} \mathrm{C}$

hung zuf Augen und Hout. giftrig

b) Behandlung von Personen

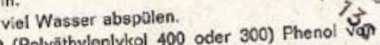

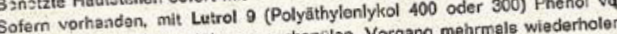
der Hatt entifarnen. M. Whasen (Windrichtung beachen).

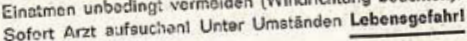

c) MaBnehmen im Brandialle Brond mit Pulverloschger alten.

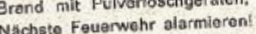

d) MaBnahmen beim Auslaufen der Ladung

Bor allen Arboiten Schutzbrililo und aturefose Phenol erotart bei ca. $40^{\circ} \mathrm{C}$, wird jedoch durch Wasser verflossig .

\section{e) Atemschute}

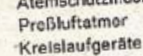

Deses Merkblatt ist bei den Versandpapieren mitzuführen

1 ies $-10000-11.20$
Transportdokumentet med retningslinjer for, hvorledes fenol skulle behandles $i$ tilfrelde af uheld. Man kunne bl a. leld. Man kunne bl.a. fare, fenol var livsfarligt, at det størknede ved ca. $40^{\circ}$, og at det kunne opløses $i$ vand. Foto: Haderslev Kriminalpoliti, pk. 1979. 
Befolkningen blev alarmeret, og i en afstand af 200 meter, 400 meter i vindretningen, blev beboere anmodet om at forlade området. I alt blev 75 personer flyttet uden for farezonen. ${ }^{7}$ Udstrømningen af fenol var på dette tidspunkt ganske voldsomt, og med direkte afløb til den offentlige kloak gennem en rist få meter bag den forulykkede bil. Brandinspektør Høyer har senere til retten fortalt, at "tilløbet af fenol til kloakken var så kraftigt, at det nærmest måtte sammenlignes med det vand, der skyller ned i en rist efter en tordenbyge". ${ }^{8}$

Den forulykkede tankvogn havde som sagt lagt sig op ad byens vandværk. Vandværksformand Jens Lauridsen Gram blev lidt før midnat ringet op af den lokale landbetjent Sønnichsen, der bad ham komme og vise hvor hovedhanen sad, så vandværket kunne lukkes. Gram tog straks af sted til ulykkesstedet, hvor der efter hans udsagn "så farligt ud ved vandværket [da] der var fenol op omkring bygningen og også ved døren". ${ }^{9}$ Han mente, det ville være for farligt at kravle hen over vognen for at komme ind i vandværket og tilbød i stedet at kravle gennem vinduet og lukke for hanen. Hans tilbud blev dog afvist og $i$ stedet gik brandinspektør Høyer og to hjælpere, alle iført røgdykkerudstyr, ind gennem døren til vandværket og afbrød såvel strøm som vandforsyningen. Selv om man forsøgte at holde fenolen ude af vandværket ved hjælp af koste, løb der formentlig på dette tidspunkt fenol ind på vandværkets gulv, der lå ca. en meter under niveau. Under alle omstændigheder blev der senere på natten konstateret fenol inde på vandværkets gulv.

I mellemtiden var politikommissær Knud Ingvard Rønne fra Haderslev blevet tilkaldt. Han ankom til ulykkesstedet omkring kl. 01 og overtog nu ledelsen af aktionen, der indtil da lidt diffust var foregået $i$ en symbiose mellem det tilstedeværende politi og brandinspektør Høyer. Rønne havde, da han blev alarmeret om ulykken, søgt kontakt med arbejdstilsynet i Kolding for at få oplysninger om fenol. Det han hørte, fik ham til at underrette både politimester H.E. Rein-Jensen og den konstituerede amtslæge L.B. Lauridsen. I Simmersted foranledigede han, at en ingeniør fra kommunen blev tilkaldt til klarlægning af kloakledninger, vandløb m.v. ${ }^{10}$

Afdelingsingeniør Henning Nielsen fra Teknisk Forvaltning i Vojens blev kontaktet af politiet. Inden han tog hjemmefra, bad han sin kone om at ringe til vejformanden og bede ham komme til stede i Simmersted med en saltvogn. Ingeniør Nielsen kørte til sit kontor i Skrydstrup og hentede her kort over vandløbssystemet, men kunne ikke finde tegnin- ger over kloaksystemet i Simmersted by. Fremme på stedet allierede han sig imidlertid med den lokale distriktsvejmand Christian Hansen, og i fællesskab fandt de frem til gennemløbsbrøndene i vejkanten. På den måde blev kloakledningen kortlagt, og man kunne konstatere, at fenol på dette tidspunkt endnu ikke var trængt frem til rensningsanlægget. ${ }^{11}$

Med en bærbar motorpumpe forsøgte ingeniør Nielsen nu at pumpe fenolen op fra en gennemløbsbrønd, men det fungerede ikke, da fenolen øjeblikkeligt krystalliserede i pumpen og gjorde den ubrugelig. En tilkaldt slamsuger blev derefter sat ind $\mathrm{i}$ forsøget på at suge fenolen op af gennemløbsbrønden. Det bevirkede uheldigvis, at en prop i kloaksystemet blev løsnet, så fenolen nu uhindret strømmede frem mod rensningsanlægget. Ganske kort tid efter kunne ingeniør Nielsen konstatere, at der var fenol i rensningsanlæggets sandfang og primærtank. For at undgå, at forureningen bredte sig til resten af rensningsanlægget og videre ud, besluttede han at tømme primærtanken med slamsugeren. Det viste sig at være en lidt større opgave end antaget, da der hele tiden løb vand til rensningsanlægget, blandt andet fordi den tilkaldte saltvogn havde optøet vejen omkring ulykkesstedet og derved skabt mere vand i kloaksystemet. Kloakristen ved ulykkesstedet var dog på dette tidspunkt blevet tildækket, så tilstrømningen af fenol og vand ebbede ud. Slamsugeren måtte i alt køre tre gange, før primærtanken var tom. ${ }^{12}$ Det opsugede vand blev i den kritiske situation ledt ud på et areal mellem kloakledningen og vandløbet ved rensningsanlægget. Da jorden var frossen mente man ikke, at det umiddelbart ville gøre skade. Næste dag blev den forurenede jord bortgravet og anbragt i et depot med kraftig plast både under og over. ${ }^{13}$

Efter denne i og for sig vellykkede indsats gik ingeniør Nielsen med en lommelygte ned til vandløbet bag rensningsanlægget for at sikre, at fenolen ikke var trængt videre. Han så ingen tegn på fenolforurening, hvilket nok - fik han at vide senere - også ville have været svært med en lommelygte, da opløst fenol ikke er synlig. Efter med andre ord at have konstateret, at forureningen var inddæmmet, gik han tilbage til ulykkesstedet ved vandværket. På dette tidspunkt havde politikommissær Rønne, stærkt forkommen, forladt stedet for at få tørt tøj på. Ingeniør Nielsen så nu også sin opgave løst og kørte hjem. Da var klokken omkring fem om morgenen. ${ }^{14}$ Til trods for den hurtige afspærring og den store opmærksomhed på fenoldampenes giftighed, blev mange personer bragt til Haderslev Sygehus til observation for forgiftning. I løbet af natten og den tidlige morgen blev således seks personer ind- 


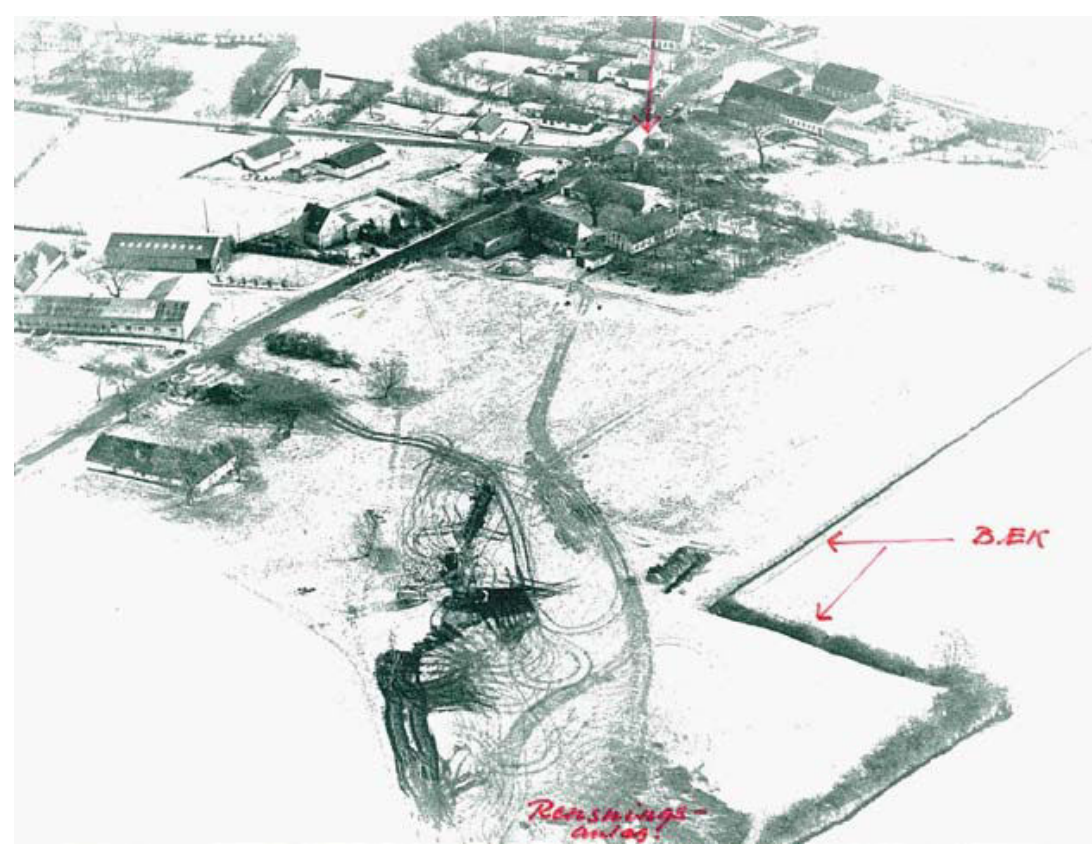

Luftfoto over Simmersted by med angivelse af ulykkesstedet øverst $i$ billedet og rensningsanlægget nederst. I højre side af billedet ses bxkken og over renseanlægget midt billedet marken, hoorpå det oppumpede vand fra rensningsanlægget blev ledt ud i løbet af natten. Foto: Haderslev Kriminalpoliti, pk. 1979.

lagt til observation. Det drejede sig foruden chaufføren om fire beboere fra området, nemlig en ældre kvinde samt en mand og hans to store knægte, Edvard Thomsen og sønnerne John og Alf, der som de første var nået frem til ulykkesstedet og havde søgt efter eventuelle tilskadekomne. Den sidste, der denne morgen blev bragt til sygehuset, var en Falck-Zonen medarbejder.

I løbet af fredagen og de næstfølgende dage blev yderligere 14 personer indlagt til observation. Heriblandt tre skolepiger på mellem $12 \mathrm{og}$ 15 år, der var cyklet forbi stedet samt to mindre børn fra området. De øvrige indlagte var tre CF-menige fra oprydningsholdet, tre kommunale medarbejdere, der ligeledes deltog i oprydningen, to Falck-Zonen reddere samt en pressefotograf. ${ }^{15}$

Alle, på nær chaufføren, blev udskrevet inden for få dage, og alle uden mén. Chaufføren slap også fra ulykken uden mén, men måtte dog tilbringe flere uger på sygehus.

\section{Fredag og lørdag den 21.-22. januar}

Fredag morgen lød det i radioavisen, at politimesteren i Haderslev advarede om, at en tankbil med farlig gift var væltet i Simmersted by, og at man antog, at den havde forurenet drikkevandet, hvorfor beboerne tilsluttet Simmersted Vandværk ikke måtte benytte vandet. Såfremt nogen følte sig utilpas, skulle de straks søge læge. ${ }^{16}$

Man stod med andre ord i Simmersted med 48 hustande uden vand til hverken morgentoilette, kaffe, madlavning eller, og det var nok det mest problematiske, til kreaturerne ved de ti landbrug, der var tilknyttet vandværket. Men takket være en hurtig indsats fra Haderslev Mælkecentral, der stillede tankvogne til rådighed, og civilforsvaret, der satte tanke op i byen, blev 40-60.000 liter vand kørt ud til Simmersted denne første dag, og også de næstfølgende dage. ${ }^{17}$

Om formiddagen ankom politimester Rein-Jensen til området, og han overtog herefter ledelsen af operationen. Også amtslæge L.B. Lauridsen var til stede for at tage analyser af vandværkets vand. Han undersøgte dog ikke bækken eller arealet rundt om ulykkesstedet, da en eventuel forurening ikke var amtslægens gebet. Hans område var det hygiejniske. ${ }^{18}$

Det stod hurtigt klart for myndighederne, at ulykken i Simmersted var ekstraordinær, og der blev tilkaldt eksperter fra nær og fjern. Fredag aften blev der holdt et såkaldt konsulterende møde om det videre oprydningsarbejde. Blandt deltagerne var foruden politimester ReinJensen og dennes souschef, politikommissær Rønne, flere ingeniører fra fabrikken i Tyskland, amtslæge L.B. Lauridsen, civilingeniørerne Kirsten Warnøe og Jørgen Lauridsen fra Sundhedsstyrelsen, geolog Niels Jessen fra Danmarks Geologiske Undersøgelser samt afdelingsingeniør Nielsen fra Vojens Kommune. Desuden havde Rockwool sendt to ingeniører fra hovedfabrikken i Hedehusene, K. Hovlund Christensen og T. Usemor, og fra fabrikken i Vamdrup, driftsleder Ejvind Mikkelsen. Det lokale civilforsvar var repræsenteret ved brandinspektør Høyer og det statslige CF ved sektionsleder F. Arpe fra Sydjyske CF-kolonne i Haderslev. Falck-Zonen var også repræsenteret ved konstitueret leder i Haderslev, assistent Svend Lynggaard. Hen på aftenen blev forsamlingen yderligere udvidet med en såkaldt katastrofemediciner fra Sverige. ${ }^{19}$

Dette store opbud af specialister til trods, stod man famlende over for situationen, men man enedes dog om lørdag morgen at forsøge at løfte den forulykkede tankvogn ved hjælp af to store BMS-kraner. Man 
frygtede, at en jernpæl havde beskadiget tanken, og at det var årsagen til udslippet. Desuden ville man forsøge at pumpe fenolen over i en anden tank. Hvis disse tiltag ikke lod sig gøre, var ekspertrådet, at man skulle lade den forulykkede tankvogn ligge, indtil fenolen var afkølet og størknet. Man antog denne fredag, at det ville ske hen over weekenden. ${ }^{20}$ Da kranerne næste morgen tog fat, skete der imidlertid et vrid i den forulykkede tank, og fenol begyndte atter at løbe ud, men dog begrænset. Ca. $16 \mathrm{~cm}$ over jorden konstaterede man, at tanken ikke var beskadiget af nogen jernpæl, og vognen blev derfor atter lagt ned for at undgå yderligere udslip.

Man gik nu over til planens anden del om at pumpe indholdet over i en anden tankvogn. I princippet en oplagt idé, men da den forulykkede tankvogn havde ligget i halvandet døgn, var der sket en vis afkøling, der sammen med udslippet havde bevirket et undertryk i tanken. Da man nu borede hul, blev trykket udlignet, og fenol begyndte atter at strømme ud i store mængder. Man opgav derfor hurtigt foretagenet, forseglede hullet og skabte atter undertryk i tanken. Herefter besluttede man at lade vognen ligge hvor den var - som en strandet hval. Området omkring bilen blev sikret med dæmninger og spærringer, og der blev bygget et telt hen over den forulykkede bil, så der ikke kunne ske yderligere ukontrollerede udslip eller forgiftninger. Nu kunne man kun afvente, at fenolen størknede i tanken..$^{21}$

Om eftermiddagen, lørdag, kom der imidlertid en ny drejning i sagen. ${ }^{22}$ Politiet blev gjort opmærksom på døde fisk i det omkringliggende å-system. Landbetjent Sønnichsen blev omkring klokken to kontaktet af en mand, der fortalte, at han allerede fredag eftermiddag havde set døde fisk. Sønnichsen gav politikommissær Rønne besked, og kørte ud til Spangså, hvor han samlede flere døde fisk op. Fiskerikontrollen blev underrettet, og overfiskeribetjent Carl Julius Salling fra Aabenraa kom til stede. Salling og Sønnichsen tog flere vandprøver i Spangså, der lå i den umiddelbare nærhed af Simmersted og som havde direkte tilløb fra bækken bag vandværket og rensningsanlægget.

Senere på dagen kom der også indberetninger om døde fisk i Nørreå, dvs. længere vestpå i å-systemet. På grund af manglende instrukser og uklarheder i kompetence mellem politi og fiskerikontrol blev der på dette tidspunkt ikke rapporteret eller advaret yderligere om faren for forurening. Muligvis var de involverede myndigheder heller ikke på dette tidspunkt helt bevidst om katastrofens omfang. Det var jo ikke første gang, at der var døde fisk i Nørreå, og tidligere havde det trods alt kun haft lokale konsekvenser. F.eks. havde der få år tidligere været et ajle-udslip ved Stepping, der havde bevirket fiskedød i åen, men allerede få kilometer længere nede ad ån var forureningen blevet så fortyndet, at den ikke længere havde betydning for fiskebestanden. Man tænkte måske, at noget tilsvarende ville gøre sig gældende denne gang. Men forureningen med fenol skulle vise sig at være af en ganske anden kaliber.

Lørdag aften ringede en lystfisker til politiet i Haderslev og fortalte om mange døde fisk ved dambruget i Fole mere end $20 \mathrm{~km}$ borte i luftlinje, omkring $35 \mathrm{~km}$ i vandlinje. Dambruget blev kontaktet, men for sent. I løbet af ganske kort tid var forureningskatastrofen en realitet med tusindvis af døde fisk. Efterfølgende afstrømningsundersøgelse foretaget af henholdsvis Isotopcentralen og Sønderjyllands Amt bekræftede formodningen om, at det var udslippet fra Simmersted, der var årsagen til forureningen. Målingerne viste, at opløst stof udledt ved Simmersted ville være mellem 33 timer (amtets måling) og 46 timer (Isotopcentralens måling) om at nå til Fole. ${ }^{23}$ Målingerne viste yderligere, at opløst stof i å-systemet ved Simmersted ville være ca. 12 timer om at passere Fole.

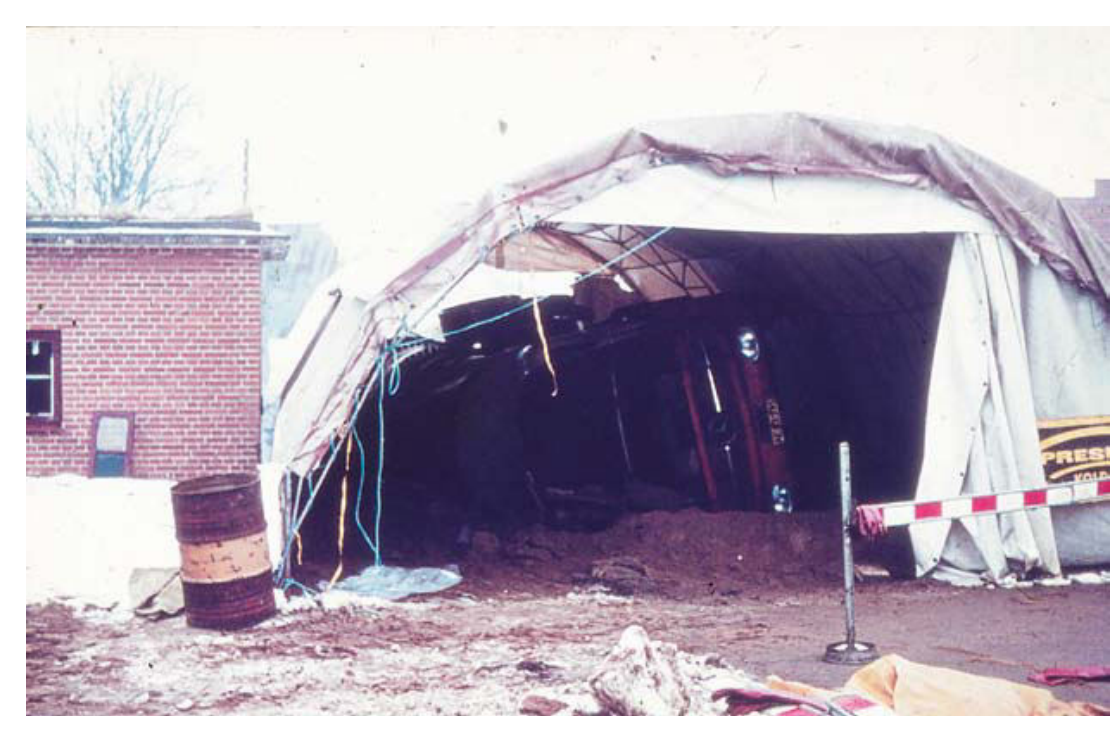

For at undgå yderligere forurening blev ulykkesbilen efter den mislykkede bjærgningsaktion den 22. januar inddæmmet med en jordvold og overdækket med et telt. Foto: Lokalhistorisk arkiv for Vojens-området. 


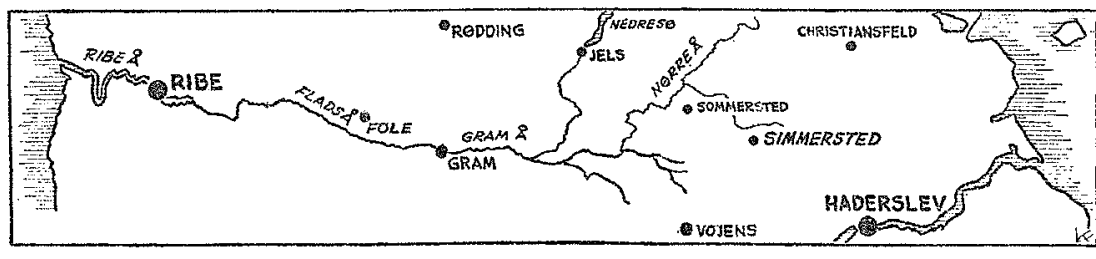

I løbet af få dage var hele å-systemet fra bækken ved Simmersted til Ribe Vesterå ved Vadehavet forurenet. En strækning på næsten 70 km. Kort: Berlingske Tidende 25/1 1972.

Landbetjent Aksel Winter fra Jels, der tog vandprøver ved dambruget, kunne senere i retten fortælle, at "der lå døde fisk i 100-vis, og [at] alle levende fisk var i stærkt oprør og sprang op af dammene mod skrænten." De forsøgte med andre ord at undslippe det giftige/syreholdige vand. Han fortalte også, at da han tog vandprøverne, mærkede han, at det prikkede i fingrene, og at det sved. ${ }^{24}$

I løbet af få dage var det værst tænkelige sket. Hele å-systemet fra bækken i Simmersted til Ribe Vesterå ved Vadehavet var forurenet med karbolsyre - opløst fenol. En strækning på næsten 70 km!

\section{Hvor kom forureningen fra?}

Man var ikke i tvivl om, at fiskedøden stammede fra ulykken i Simmersted. Politimesteren meddelte således i radioavisen: "Foranlediget af, at der i Spangså, Nørreå, Fole Dambrug, Ribe Å ud mod Vadehavet samt tilstødende vandløb er fundet døde fisk og enkelte fugle, advares befolkningen samt evt. lystfiskere og turister mod at komme i berøring med vandet, fiskene og evt. døde fugle, da det kan befrygtes, at der - som følge af tankvognskatastrofen i Simmersted ved Haderslev er sket en fenolforgiftning af de nævnte vandløb. Det advares samtidig mod at anvende vand fra de nævnte vandløb til vanding af husdyr eller til andet brug". ${ }^{25}$ Det var imidlertid gådefuldt, hvordan fenolen var kommet ud i bækken og videre ud i å-systemet. Kloakken var jo blevet sikret ved rensningsanlægget allerede samme nat som ulykken fandt sted, og gennem vandværksvandet kunne det heller ikke være sket, da vandværket ligeledes var blevet lukket umiddelbart efter midnat. Løbende havde man pumpet fenolholdigt kloakvand op af brøndene, så det ikke ad den vej spredte sig. Fakta var imidlertid, at bækken i Simmersted var blevet forurenet med fenol. Kunne det være nedsivning fra den tilstødende mark, hvorpå man havde udtømt vandet fra rensningsanlæggets pri- mærtank om natten? Kunne det være udsivning ind over markerne fra selve ulykkesstedet? Måske et utæt kloakrør? Man var i vildrede. En sandsynlig forklaring kom imidlertid søndag eftermiddag, da "én eller anden" fra byen fortalte ingeniør Nielsen fra Vojens Kommune, at vandværkets gulvafløb ikke var tilsluttet kloaksystemet, men at det løb ud i et dræningsrør i marken bagved, der igen førte ned til bækken helt uden om det kommunale kloaksystem. ${ }^{26}$

Man gik straks i gang med at grave vandværkets afløbsledning op og fandt den stoppet med størknet fenol.

I løbet af weekenden og mandagen anlagde Civilforsvaret en 2,5 km lang rørledning fra nabobyen Maugstrup med opkobling til det lokale net. ${ }^{27}$ Den hurtige lukning af vandværket betød, at ledningsnettet $\mathrm{i}$ byen formentlig ikke var inficeret med fenol. Og som dagbladet Sønderjyden beroligende kunne skrive, hvis det modsatte alligevel skulle være tilfældet, så ville man hurtigt kunne smage, om der var fenol i vandet $!^{28}$ Med fiskedøden in mente, var det nok de færreste, der havde lyst til at smage sig frem. Amtslægen var da også mere forsigtig, da ledningsnettet skulle tages i brug. Om mandagen udsendte han en meddelelse til beboerne i Simmersted, hvori han bad dem hjælpe med ved en gennemskylning af ledningsnettet. Mellem klokken 18.30 og 19.30 skulle alle tilknyttet vandværket således tænde for hanerne og udskylle toiletterne mindst fire gange..$^{29}$ Han pointerede, at skyllevandet ikke måtte bruges til noget, og at vandet fra ledningsnettet først måtte tages i anvendelse, efter der var taget vandprøver, og myndighederne gennem skriftlig besked havde givet tilladelse. Den kom om onsdagen. Indtil da, fik man vand leveret med tankbil.

Selve oprydningen af ulykkesstedet foran vandværket trak ud, da fenolen i den forulykkede tankbil kun langsomt lod sig afkøle, og betydeligt langsommere end eksperterne havde forudset. Først på et såkaldt ekspertmøde onsdag den 9. februar, det vil sige 20 dage efter ulykken, mente man, at fenolen nu var så afkølet/størknet, at der ikke længere ville være fare for nye udslip ved en flytning af tanken. Kommunekemi A/S blev, med et tilbud på 10.000 kr., hyret til borttransport af ulykkesbilen og oprydning på stedet. Såfremt det ikke regnede, ville bilen blive fjernet mandag den 14 . februar - altså hele 25 dage efter, at ulykken var sket. ${ }^{30}$

Hvor meget fenol var der så løbet ud i den mellemliggende periode? Man vidste det faktisk ikke, men på mødet den 9. februar nåede eksperterne frem til, at der fortsat var omkring 10.000 liter i tanken. Fire 


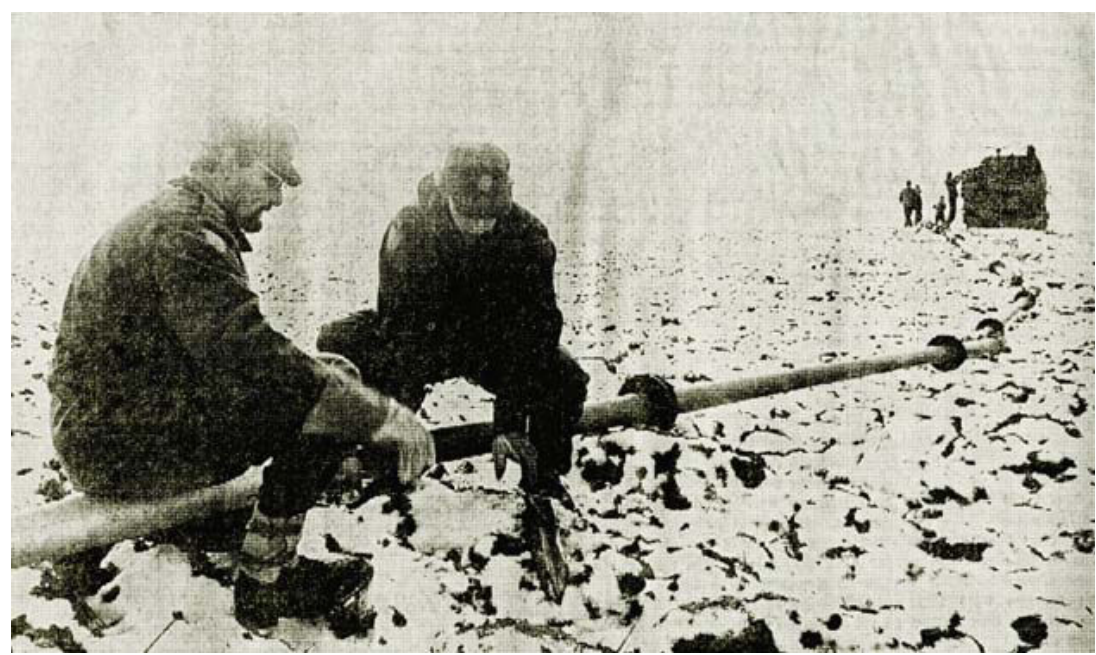

I løbet af weekenden og mandagen udlagde civilforsvaret en 2,5 km lang rørledning fra vandværket i Maugstrup til Simmersted. Foto: Lokalhistorisk arkiv for Vojens-området.

tons størknet fenol var på dette tidspunkt kørt til Kommunekemi og 3,8 tons til Rockwool i Vamdrup. Dertil kom tre-fire tons fenolholdigt kloakvand, der ligeledes var kørt til Kommunekemi i Nyborg. Desuden regnede man med, at der fortsat lå omkring et tons størknet fenol under den forulykkede vogn. Så alt i alt blev regnestykket, at omkring et ton fenol var forsvundet, enten ned i jorden eller ud i å-systemet. ${ }^{31}$

Umiddelbart lød det af meget, men til trods for dette, kunne politimesteren allerede 1. maj trække politibekendtgørelsen om ikke at anvende vand fra Spangså, Nørreå, samt Ribe Å tilbage. ${ }^{32}$ Og også i Simmersted by så det i foråret 1972 lyst ud. I forbindelse med oprydningen udtalte direktør Peter Stausholm fra Kommunekemi, at han regnede med, at Simmersted fuldstændig ville have overstået ulykkens følger senest om et halvt år. ${ }^{33}$

\section{Simmersted Vandværk}

Det positive budskab gjaldt dog ikke vandværket. Faktisk gik ulykkens konsekvenser først rigtig op for beboerne i Simmersted, efter at tankvognen var fjernet, for man vendte ikke tilbage til dagligdagen før ulykken, og tingene var ikke som de havde været før. Det store problem var vandforsyningen, idet vandværket fortsat var lukket.
I Simmersted var man mest stemt for en fortsættelse af det private vandværk med en ny boring i tilpas afstand fra forureningen, men Sundhedskommissionen i Vojens Kommune indstillede til Kommunalbestyrelsen, at der ikke skulle oprettes et nyt vandværk i Simmersted. I stedet anbefalede man, at vandforsyningen fremover skulle ske gennem en permanent tilslutning til Maugstrup. ${ }^{34}$ Dette ville imidlertid blive betydeligt dyrere end de ca. $30.000 \mathrm{kr}$. en ny brønd ville koste, formentlig ville det beløbe sig til mellem 60 og $75.000 \mathrm{kr}$., men argumentet var, at selv med en ny boring skulle der løbende tages prøver, og viste det sig så, at grundvandet alligevel var forurenet, ville alle pengene være spildt. ${ }^{35}$

Det altoverskyggende problem var imidlertid, hvem der skulle betale for den nye vandforsyning. Det private vandværk i Simmersted havde ingen penge og var i forvejen i gæld. Og hverken beboerne i Simmersted eller i Maugstrup mente, at de skulle bære byrden. De var jo ganske uforskyldt i ulykken. Begge vandværker indkaldte til ekstraordinære generalforsamlinger. I Simmersted erkendte man efter en livlig debat, at der ikke var fremtid i deres eget vandværk, og med $90 \%$ af andelshaverne i ryggen blev bestyrelsen bemyndiget til at forhandle med Maugstrup Vandværk om en tilslutning. ${ }^{36}$

Sagen fik dog en ny drejning, da andelshaverne i Maugstrup dagen efter, onsdag den 1. marts, overhovedet ikke ville have Simmersted med. ${ }^{37} \mathrm{Om}$ det var gammel nabostrid, der lå til grund er svært at sige, men udmeldingen blev bestemt ikke positivt modtaget i Simmersted. Her begyndte man nu at tale om sabotage af den midlertidige vandledning, og stemningen svingede atter over mod en fortsættelse af eget vandværk, evt. gennem en tilslutning til gårdejer Poul Nielsens private brøndboring på 34 meter og med kapacitet på 10.000 liter vand i timen. Et møde torsdag den 2. marts mellem de to bestyrelser og de kommunale myndigheder endte uden resultat, da bestyrelsen for Maugstrup ikke havde mandat til forhandling. Under mødet fik borgmester Terkel Jensen overbragt en protestskrivelse, underskrevet af 38 af Simmersteds 48 andelshavere, heriblandt tre bestyrelsesmedlemmer. I protesten hed det: "Vi forlanger midlertidig tilslutning til Poul Nielsens boring, indtil vort eget vandværk er bragt $i$ stand. Hvis myndighederne fastholder, at vi skal tvangsindlægges under Maugstrup Vandværk, må vi forlange, at vi bliver holdt fuldstændig skadesløse. Vi meddeler samtidig, at vi under ingen omstændigheder vil sætte os i yderligere gæld. Hvis ikke de lokale myndigheder vil efterkomme vore ønsker, agter vi at gå til højere instanser." 38 
Situationen skærpedes yderligere lørdag den 11. marts, hvor vandledningen flere steder blev frostsprængt. Atter talte man i Simmersted om sabotage i form af fjernelse af isoleringsmateriale rundt om ledningen, fjernede gummimuffer og nedsat pumpeeffekt i Maugstrup, så vandet lettere frøs i ledningen. Selv om mælkecentralen atter hurtigt kom på banen med vandforsyning, havde fem landmænd tilknyttet vandværket denne weekend brugt vand fra den gamle brønd til deres kreaturer. Da mælkecentralen hørte dette, ville de i første omgang ikke tage imod mælk fra de pågældende, men da en efterfølgende analyse af vandet viste, at det ikke indeholdt fenol, tog man dog mod mælken, men betingede sig med underskrift, at det ikke ville gentage sig i fremtiden. ${ }^{39}$

Vojens Kommune indbød nu til et fællesmøde på Maugstrup Kro den 14. marts i håb om, at der kunne findes en mindelig løsning..$^{40}$ Mødet endte atter uden resultat, og kerneproblemet var pengene. Som det stod i dagbladet Dannevirkes referat dagen efter, så var de omkring 75 tilstedeværende beboere fra Maugstrup og Simmersted ikke enige om alt, og slet ikke om den praktiske løsning på vandforsyningen til Simmersted. Ét kunne man dog stå fælles om, nemlig at den uheldige situation man befandt sig i, var aldeles uforskyldt. Hvis der fandtes nogen form for retfærdighed, så var det ikke beboerne i de to landsbyer, der skulle betale gildet.

Situationen var nu ved at gå i hårdknude. De to vandværksbestyrelser viste sig dog i situationen at være deres ombud værdigt. Sammen udarbejdede de et forslag til en samarbejdsaftale. Den betød ganske vist, at samtlige udgifter skulle betales af Simmersted, tillige med at hver hustand skulle betale tilslutningsafgiften på $800 \mathrm{kr}$., men med udsigt til en klækkelig erstatning fra vognmanden ville byrden næppe heller blive så stor. Ved en ekstraordinær generalforsamling i Simmersted fredag aften den 24. marts gik bølgerne højt, men man endte med at give forslaget tilslutning. Man måtte se realiteterne i øjnene: Det var nødvendigt atter at få etableret en normal vandforsyning $\mathrm{i}$ byen. ${ }^{41}$

Allerede medens oprydningsarbejdet stod på, meldte spørgsmålet sig, hvorledes en sådan ulykke kunne ske, og hvordan den kunne få så store forureningsmæssige konsekvenser. Civilforsvaret måtte blankt erkende, at deres beredskab primært var lagt an på ABC-tjeneste, dvs. indsats i forbindelse med atomar-, biologisk- og kemisk krigsførelse, ikke på ulykker som i Simmersted. Kolonnechef S.E. Plougheld fra Hillerød udtalte f.eks. til dagbladet Aktuelt, at "man aner end ikke, hvad fenol er, og vi aner ikke, hvad vi skal gøre, hvis der sker en giftulykke som den i
Sønderjylland." 42 Også dagbladet Information undrede sig: "Fenolkatastrofen [...] er endnu et bevis på, hvor dårligt samfundet er beredt på at kæmpe med de nye farer, der truer store og små efter de sidste generationers løbske tekniske udvikling. Vi har i større eller mindre omfang forberedt os på at modstå en række traditionelle farer (krig, brand m.m.), men alle bliver forvirrede, når en ganske almindelig tankvogn vælter, og dens giftige indhold begynder at løbe ud på jorden. Man kender ikke giften, selv om man får at vide, hvad den hedder, og myndighederne står usikkert overfor, hvordan hele problemet skal gribes an." 43

Direktøren for Kommunekemi, Peter Stausholm, gned salt i det lokale sår med en udtalelse om, at fenolulykkens omfang i Simmersted kunne være undgået, hvis redningsarbejdet var blevet ledet af en kemiker og ikke en jurist, underforstået af politimesteren. Han mente, at redningsog oprydningsarbejdet blev forkludret på grund af alt for mange sikkerhedsforanstaltninger. Man skulle efter hans mening straks have skåret undervognen fra tanken, og dernæst trillet beholderen over på en blokvogn og kørt den til Kommunekemi A/S. Dernæst kunne man, som han sagde, være gået i gang med at fjerne jord og vand. ${ }^{44}$ Han blev dog klart imødegået af den konstituerede leder af Falck-Zonen i Haderslev, assistent Svend Lynggaard, der dagen efter til Jydske Tidende udtalte,

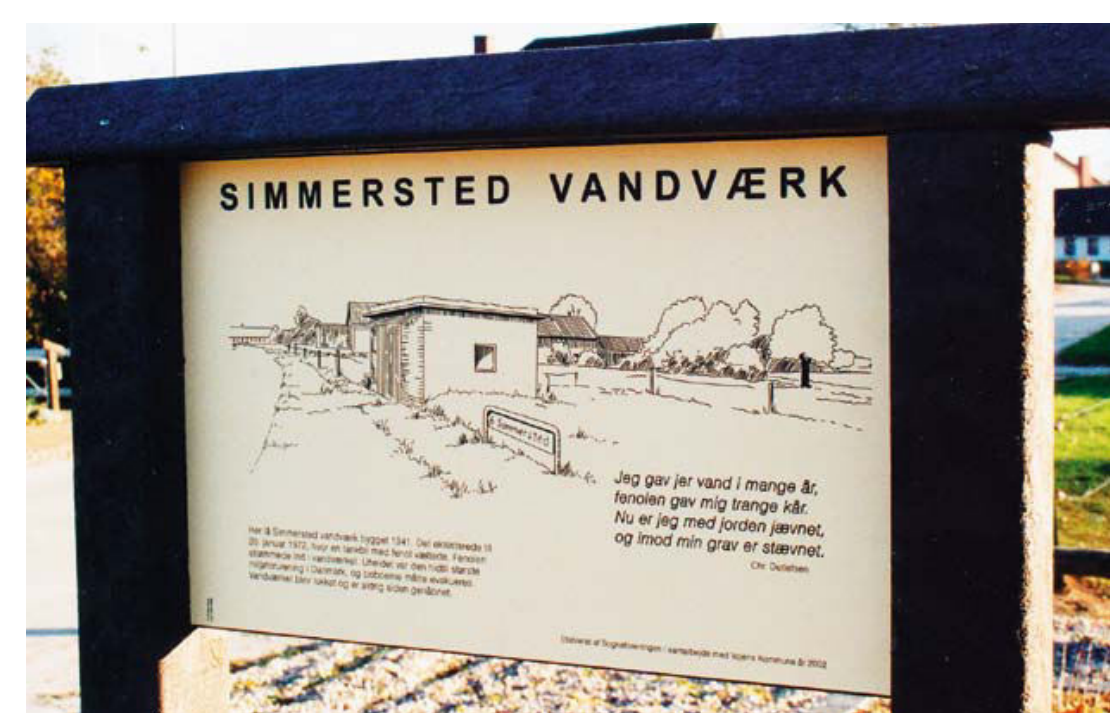

Hvor vandværket lå, er der nu indrettet et lille anlæg og opsat en mindetavle til erindring om ulykken. Foto: Lokalhistorisk arkiv for Vojens-området. 
at "Stausholm har måske forstand på kemikalier, men den tank lod sig ikke uden videre rulle om på en blokvogn. Tanken var simpelt hen ikke stærk nok til at blive krænget over. Så ville den være knækket." 45

Ikke overraskende blandede mange sig i debatten om ulykken og hvad der burde være gjort. Lidt spydigt havde Dannevirke allerede den 26. januar en overskrift, der lød: "Bagefter er alle kloge". Politimester Rein-Jensen udtalte flere gange i forløbet, at det eneste ekspertråd, han havde fået, var at lade det hele ligge, indtil det var afkølet og ikke længere var farligt. Det var det råd, han fulgte. ${ }^{46}$

\section{Det retslige efterspil}

Med fjernelsen af vognen og oprydningen ved vandværket var fenolsagen langt fra afsluttet. En lang række økonomiske krav blev nu stillet, og ansvaret skulle placeres. Det retslige efterspil foregik dels ved Kriminalretten i Haderslev, hvor henholdsvis chauffør og vognmand stod tiltalt for overtrædelse af færdselsloven, dels i et civilt søgsmål om erstatningspligten ved, i første omgang, Retten i Kolding, senere ved Vestre Landsret. Ved Retten i Haderslev blev chauffør Erik Nielsen den 23. juni 1972 idømt en bøde på $1.000 \mathrm{kr}$. med en forvandlingsdom på 10 dages hæfte for overtrædelse af færdselsloven, og vognmand K. E. Kruse en bøde på 4.000 kr. med forvandlingsdom på 30 dages hæfte for samme forseelse. ${ }^{47}$ Mange mente, at det var milde domme, men dommen vedrørte som sagt kun overtrædelsen af færdselsloven, ikke ulykken eller erstatningspligten. Dette spørgsmål skulle afklares ved det civile søgsmål.

Den lovpligtige forsikring for tingsskade var på 120.000 kr., og det var den forsikring vognmand K. E. Kruse havde tegnet for ulykkesbilen i Simmersted. Beløbet var dog ganske utilstrækkeligt i forhold til de erstatningskrav, der blev rejst. Alene fra Fole Dambrug var der et erstatningskrav på knap 550.000 kr., og fra de berørte sportsfiskerforeninger nævntes et erstatningskrav på omkring 360.000 kr. Simmersted Vandværk kom med et erstatningskrav på $180.000 \mathrm{kr}$. Dertil kom en del mindre erstatningskrav fra berørte gårdejere i området, som havde fået jord og evt. dyr forurenet. Endelig krævede Justitsministeriet omkring 300.000 $\mathrm{kr}$. til dækning af omkostningerne i forbindelse med oprydningen. ${ }^{48}$

Dette opbud af erstatningskrav fik vognmandens advokat, landsretssagfører Jørgen Jacobsen fra København, til at pege på, at ulykkens omfang specielt skyldtes myndighedernes mange fejltagelser. Han ud-

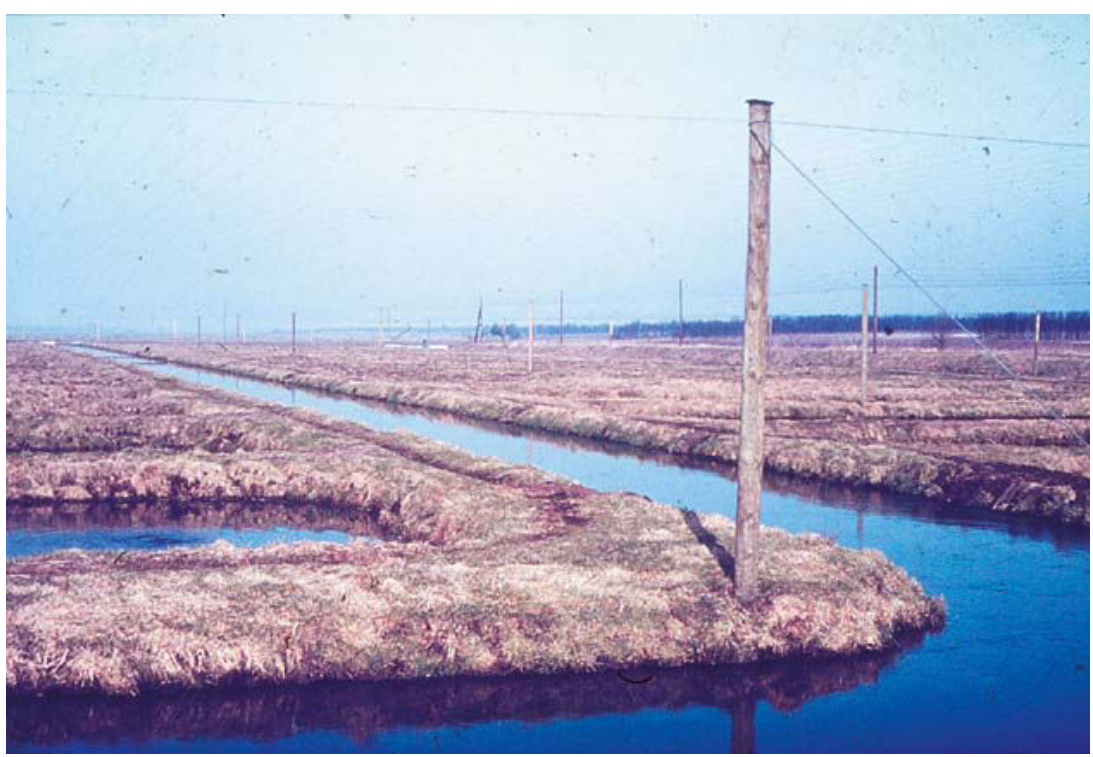

Ved Fole Dambrug, mere end $30 \mathrm{~km}$. borte, døde fisk i tusindvis. Det foranledigede et erstatningskrav fra dambruget på $550.000 \mathrm{kr}$. Foto: Lokalhistorisk arkiv for Vojensområdet.

talte bl.a., at: "Hele redningsarbejdet efter ulykken forekommer ikke særlig kompetent. Og det er mit standpunkt, at det er myndighederne bag redningsarbejdet, som må stå til ansvar for forureningsfølgerne." ${ }^{\prime 4}$ Samme tanke var også Fole Dambrugs advokat, landsretssagfører Johs. F. Gravesen, Viborg, inde på i sin anmeldelse af erstatningskravet. Muligvis var der dog her lige så meget tale om en helgardering i forhold til overhovedet at få erstatning: "Erstatningen rejses navnlig over for vognmand E. Kruse og hans forsikringsselskab Baltica. Endvidere forbeholdes erstatningskrav over for de myndigheder, som kan være erstatningspligtige i anledningen af, at underretning om faren ikke i tide blev meddelt til dambruget eller i øvrigt bekendtgjort offentligt." ${ }^{50}$ Ved den efterfølgende sag blev der udtaget stævning mod både Simmersted Vandværk samt politimester Rein-Jensen. Vandværket fordi fenol kunne løbe gennem gulvristen ud i bækken, og politimesteren i hans egenskab af leder af katastrofearbejdet.

Med nogenlunde samme argumentation som de andre involverede parter, nedlagde vognmand Kruses forsikringsselskab, Baltica, gennem deres advokat påstand om frifindelse for ansvar, da selve ulykken var 
at regne for et hændeligt uheld, samt at hverken vognmand eller forsikringsselskab kunne drages til ansvar for så fjerne og upåregnelige følger som forureningen af Fole Dambrug mere end $30 \mathrm{~km}$ borte. Ligeledes hævdede man, at det havde været helt upåregneligt for vognmanden, at der i vandværket var et afløb uden om byens kloak. Faktisk gjorde man i svarskriftet til det civile søgsmål gældende, at et eventuelt ansvar for fenolens mulige skadelige følger var overgået til de offentlige myndigheder, repræsenteret ved politimesteren i Haderslev, fra det øjeblik politiet var ankommet til ulykkesstedet om natten den 20 . januar og havde overtaget redningsarbejdet. ${ }^{51}$

Alle implicerede parter kørte sig med andre ord i stilling i forhold til det retslige efterspil om erstatning, også det offentlige med kravet om 300.000 kr. Med et sådant krav ville man nemlig opnå en processuel fordel ved at stå som sagsøger på linje med de øvrige erstatningssøgende frem for som anklagede..$^{2}$

Efter indledende afhøringer ved Retten i Kolding blev sagen 31. januar 1973 videresendt til Vestre Landsret, men inden sagen blev behandlet dér, blev der i efteråret 1974 mellem de berørte parter udarbejdet et forlig, som blandt andet betød, at det offentlige gav afkald på sine fordringer til fordel for de øvrige erstatningssøgende, mod at de på den anden side gav afkald på de over for statskassen, de involverede kommuner og Simmersted Vandværk rejste eller forbeholdte krav. ${ }^{53}$ Et nogenlunde tilsvarende forlig havde allerede været på tale i foråret 1974 , men da med blot 17.000 kr. i erstatning til Simmersted Vandværk. Dette kunne vandværket ikke tiltræde, hvorfor man opretholdt kravet om at få sagen afgjort ved dom. ${ }^{54} \mathrm{Nu}$, med en nye fordeling af erstatningsbeløbet, blev forliget accepteret af vandværket, og alle parter, dvs. forsikringsselskabet Baltica, Fole Dambrug, Simmersted Vandværk, Vojens Byråd, Gram Kommunalbestyrelse, vognmand Kruse samt Statsadvokaten, som det offentliges repræsentant, tiltrådte forliget hen over vinteren 1974-75.

Ifølge forliget blev erstatningsbeløbet fordelt med 2/3 til Fole Dambrug og 1/3 til Simmersted Vandværk. Af vognmand Kruse fik dambruget et pantebrev på $66.665 \mathrm{kr}$. og vandværket et tilsvarende på 33.335 kr., dvs. i alt 100.000 kr., der skulle betales over de næste ti år. Forsikringsselskabet udbetalte forsikringssummen på $120.000 \mathrm{kr}$. fordelt med 80.000 kr. til Fole Dambrug og 40.000 kr. til Simmersted Vandværk. Hele beløbet blev dog ikke udbetalt straks, da 38.700 kr. - et forholdstal i forhold til det formodede erstatningskrav - blev indsat på en spærret konto til betaling af eventuelle erstatningskrav fra sportsfiskerforeningerne. Udeblev dette erstatningskrav med forældelsesfrist 7. februar 1977 , ville pengene tilfalde dambrug og vandværk.

Som et lille kuriosum på erstatningssagerne kan det nævnes, at Edvard Thomsen og hans to sønner, der som de første ved ulykkesstedet havde søgt efter eventuelle tilskadekomne, over for vognmandens forsikringsselskab havde bedt om en erstatning på i alt 807 kr. som kompensation for tabt arbejdsfortjeneste under deres indlæggelse på Haderslev Sygehus. Dette meget rimelige krav fik imidlertid forsikringsselskabets advokat til at sende et meget afvisende, belærende og ufølsomt brev til Edvard Thomsen og hans to sønner: "Erstatningspligten bestrides, da selve væltningen skyldtes hændelige forhold. De og Deres sønner burde have holdt Dem på afstand af den væltede tankbil og de udstrømmende fenol-dampe, der ret hurtigt måtte kunne erkendes som værende giftige, hvilket i øvrigt straks blev oplyst af føreren af tankbilen. I hvert fald havde det været tilstrækkeligt om en af Dem var gået hen til tankbilen for at undersøge, om hjælp var påkrævet." 55

Brevets tone fik Edvard Thomsen til i retten at betegne det som "møgbeskidt", hvilket indkasserede ham en henstilling fra dommeren om ikke at bruge den slags udtryk. Retfærdigvis skal det dog nævnes, at forsikringsselskabet kom på bedre tanker og ved retssagens start i Haderslev indvilgede $i$ at betale beløbet af kulance, uden dog dermed at tage stilling til skyldsspørgsmålet.

\section{Ny miljøbeskyttelseslov}

Ulykken gav dønninger uden for Simmersted og Sønderjylland og fik betydning for den fremtidige danske miljølovgivning samt indsats over for forureningsbekæmpelse gennem udarbejdelse af beredskabsplaner.

Allerede få dage efter ulykken, den 2. februar 1972, stillede Niels Jørgen Nielsen fra Venstre ministeren for forureningsbekæmpelse, Jens Kampmann, følgende spørgsmål i Folketinget: "Vil ministeren sikre, at industriel anvendelse og transport af særlig farlige kemikalier o. lign. kommer til at foregå under mere betryggende forhold end hidtil, samt at der sikres en tilstrækkelig koordination mellem forskellige myndigheder, herunder civilforsvaret og forsvarets eksperter, til imødegåelse af følgerne af omfattende giftulykker i forbindelse med transport, produktion m.v.?"56 Ministeren svarede, at ulykken ved Simmersted klart havde vist, at der var behov for regler på området. Derfor havde han 
taget skridt til, at der snarest blev igangsat et arbejde, der kunne sikre en effektiv indgriben ved lignende katastrofesituationer.

Også Mogens Camre fra Socialdemokratiet stillede samme dag spørgsmål i Folketinget om ulykken. ${ }^{57}$ Han spurgte justitsministeren, K. Axel Nielsen, hvilke foranstaltninger han påtænkte at gennemføre for at forebygge forureningskatastrofer i forbindelse med transport af giftstoffer? Camre begrundede blandt andet sit spørgsmål med, at de bestemmelser, der fandtes på området - en bekendtgørelse fra 1932 talte om, at man ved transport af giftstoffer skulle køre med et pålideligt forspand, og at bagsmækken skulle være af en sådan styrke, at tromlerne ikke faldt ud. Foregik transporten med bil, måtte hastigheden i henhold til bekendtgørelsen ikke overstige $30 \mathrm{~km}$ i timen. Af justitsministerens svar fremgik det, at der i 1968 var udarbejdet en international konvention om transport af farligt gods, men at intet nordisk land endnu havde tiltrådt den, heller ikke Danmark. Videre fremgik det af svaret, at han med udgangspunkt i den rapport, politimesteren i Haderslev havde udarbejdet om ulykken i Simmersted, ville tage skridt til at sikre tilfredsstillende regler for transport af farligt gods. Sammen med ministeren for forureningsbekæmpelse og andre berørte myndigheder og styrelser, ville han desuden fastlægge de nærmere retningslinjer for en effektiv indsats. Dette arbejde ville "på den givne foranledning" blive fremskyndet.

Allerede den 18. maj 1972 kunne ministeren for forureningsbekæmpelse fremsætte et forslag til lov om miljøbeskyttelse. Den blev førstebehandlet den 29. maj, lige inden Folketingets sommerferie, hvorefter det blev sendt til udvalgsbehandling. ${ }^{58}$ Ved genfremsættelsen næste år, den 25. januar 1973, var lovforslaget ændret på visse punkter og udvidet, men formålet var fortsat, at "forebygge og bekæmpe forurening af luft, vand og jord", som der stod i §1. Loven omfattede al virksomhed, der kunne give anledning til forurening, og herunder også "transport af stoffer med farlige egenskaber" (\$2)..$^{59}$ Lovforslagets hovedprincipper var en samling og koordinering af myndighedernes indsats i forureningsbekæmpelse. På det centrale plan samledes administrationen i den nyoprettede Miljøstyrelse, på lokalt og regionalt plan hos kommunalbestyrelse og amtsråd. Samtidig blev de lokale sundhedskommissioner nedlagt, ligesom landvæsenskommissionernes opgaver på området blev kraftigt begrænset. Et andet vigtigt princip i den nye lov var, at hændelser og stoffer, der kunne give anledning til forurening, skulle forhåndsgodkendes af miljømyndighederne, samt at der med lovgivningen kom ensartede regler for hele landet.

Der var tale om en rammelov, der skulle udfyldes gennem de administrative myndigheders konkrete afgørelser samt gennem bekendtgørelser og cirkulærer, herunder også udarbejdelsen af lokale miljøberedskabsplaner. Loven trådte i kraft i 1974, samtidig med at ministeriet skiftede navn til Miljøministeriet. Loven har, skønt ændret og udvidet adskillige gange, været grundstammen i den danske lovgivning om forureningsbekæmpelse lige siden.

\section{Sammenfatning}

Inden for kaosteorien taler man om, hvordan en sommerfugls vingeslag i Sydamerika under de rette omstændigheder kan forårsage orkan i Nordamerika. Lidt på samme måde var det med fenolulykken i Simmersted. Det, der umiddelbart var et banalt glatføreuheld i en lille sønderjysk landsby, udviklede sig i løbet af timer og dage til at blive en forureningskatastrofe af hidtil usete dimissioner i dansk sammenhæng.

Ulykkens omfang skyldtes egentlig ikke, som det den gang og senere ofte er blevet antydet, at myndighederne tog let eller lemfældigt på opgaven. Tværtimod! Gennemgår man nøgternt forløbet, forsøgte alle involverede parter faktisk at reagere både hurtigt og fornuftigt: Politi og ambulance kom straks til stede, der blev afspærret, folk blev evakueret, vandværket blev lukket, forureningen af kloak og rensningsanlæg blev stoppet, der blev pumpet forurenet vand bort, den forulykkede tankbil og den udstrømmende fenol blev forsøgt nedkølet med kulsyre, man indkaldte den ypperste ekspertise, tankbilen blev forsøgt rejst og tømt osv., men det forhindrede ikke forureningen. Og hvorfor ikke? Fordi man ganske enkelt stod uden fortilfælde og uden erfaring. Der var ikke udarbejdet planer og kommandoveje til en sådan situation, og ingen af de involverede parter havde fantasi til at forestille sig, at der fra risten i gulvet på Simmersted Vandværk kunne brede sig en forurening 50 til $70 \mathrm{~km}$ bort.

Selvfølgelig var Simmerstedulykken ikke den eneste udløsende faktor i forhold til den nye miljøbeskyttelseslov. Det forberedende arbejde havde stået på i længere tid, men ulykken var på godt og ondt en øjenåbner over for den brede offentlighed og var på den måde med til, at Danmark, som det første land i verden, fik et egentligt Miljøministerium, og i forlængelse heraf, en Miljøbeskyttelseslov. 


\section{KILDER}

Utrykte kilder:

Rigsarkivet København (RAK):

Justitsministeriet nr. 809 og 810: Journalsag 240-53.

Rigsarkivet Aabenraa (RAÅ):

Haderslev Kriminalpoliti, Akter vedrørende fenolsagen, nr. 1978: I Anklageskrift, fotos, nr. 1979: II Vandværk, regninger,

\section{NOTER}

1 Efter chaufførens vidneforklaring ved Retten i Haderslev samt politirappor (RAÅ, Haderslev Kriminalpoliti, Akte vedrørende fenolsagen, nr. 1978)

2 Vidneforklaring fra Kolding Herredsret (RAÅ, Haderslev Kriminalpoliti, Akter vedrørende fenolsagen, nr. 1978) samt avisartikel i Danevirke 21.1.1972.

3 Som ovenfor, note 1 og 2 .

4 Ibid.

5 Ibid. samt rapport fra Statens Bilinspektion, Haderslev (RAÅ, Haderslev Kriminalpoliti, Akter vedrørende fenolsagen, nr. 1978).

6 Minutrapport fra Haderslev Politistation (RAÂ, Haderslev Kriminalpoliti, Akter vedrørende fenolsagen, nr. 1980).

7 Rapport afgivet til Justitsministeriet over hændelsesforløbet i sagen, dateret 7. apr. 1972 (RAÅ, Haderslev Kriminalpoliti, Akter vedrørende fenolsagen, nr. 1980).

8 Vidneforklaring, Kolding Herredsret (RAÅ, Haderslev Kriminalpoliti, Akter vedrørende fenolsagen, nr. 1978)

9 Ibid.

10 Ibid. samt rapport afgivet til Justitsministeriet, dateret 7. apr. 1972 (RAÅ, Haderslev Kriminalpoliti, Akter vedrorende fenolsagen, nr. 1978 og 1980).

11 Vidneforklaring, Kolding Herredsret (RÅ̊, Haderslev Kriminalpoliti, Akter vedrørende fenolsagen, $n r$. 1978)

12 Ibid.

13 Foreløbig rapport over indsatsen ved fenolulykken i Simmersted, dateret 26. jan. 1972 og udarbejdet af H.J. Nielsen. (RAK, Justitsministeriet, nr. 809, journalsag 240-53'). presseudklip, nr.. 1980: III Arbejdsmappe for P. A. Mortensen, nr. 1981: IV Underbilag og nr. 1982: V Politimesteren.

\section{Trykte kilder:}

Folketingstidende 1972-73, 1973-74.

Folketingets forhandlinger 1973-74.

Dannevirke.

Jydske Tidende.

Sønderiyden.

14 Vidneforklaring, Kolding Herredsre (RAÅ, Haderslev Kriminalpoliti, Akte vedrørende fenolsagen, nr. 1978)

15 Opgørelse over indlagte på sygehus (RAK, Justitsministeriet, nr. 810, journalsag 240-53"I).

6 Telex 210230 til radioavisen (RAÅ, Haderslev Kriminalpoliti, Akter vedrørende fenolsagen, nr. 1980).

17 Se f.eks. Dannevirke, Sønderjyden m.fl. aviser den 22. jan. 1972.

18 Vidneforklaring, Kolding Herredsret (RAA, Haderslev Kriminalpoliti, Akter vedrørende fenolsagen, nr. 1978).

19 Rapport afgivet til Justitsministeriet over hændelsesforløbet i sagen, dateret 7. apr. 1972 (RÅ̊, Haderslev Kriminalpoliti, Akter vedrørende fenolsagen, nr. 1980) samt avisartikler, f.eks. Jyske Tidende den 22. jan. 1972.

20 Som ovenfor.

21 Rapport afgivet til Justitsministeriet over hændelsesforløbet i sagen, datere 7. apr. 1972 (RAA, Haderslev Kriminalpoliti, Akter vedrørende fenolsagen nr. 1980)

22 Dette afsnit bygger primært på minutrapporten fra Haderslev Politistation samt vidneudsagnene ved Kolding Herredsret (RAÅ, Haderslev Kriminalpoliti, Akter vedrørende fenolsagen nr. 1980 samt 1978)

23 Justitsministeriet nr. 810, journalsag 240-53', samt rapport afgivet til Justitsministeriet over hændelsesforløbet sagen, dateret 7. apr. 1972 (RÅ̊, Haderslev Kriminalpoliti, Akter vedrørende fenolsagen, nr. 1980)
24 Vidneforklaring, Kolding Herredsret (RAÅ, Haderslev Kriminalpoliti, Akte vedrørende fenolsagen, nr. 1978).

25 Telex 230550 til radioavisen (RAÅ, Haderslev Kriminalpoliti, Ak
rende fenolsagen, nr. 1980).

26 Vidneforklaring, Kolding Herredsre (RAÅ, Haderslev Kriminalpoliti, Akte vedrørende fenolsagen, nr. 1978).

27 Se f.eks. Jydske Tidende m.fl. aviser den 25.-26. jan. 1972.

28 Sønderjyden den 25. jan. 1972.

29 Jydske Tidende den 25. jan. 1972.

30 Rapport afgivet til Justitsministeriet over hændelsesforløbet i sagen, dateret 7. apr 1972 (RÅ̊, Haderslev Kriminalpoliti, Akter vedrørende fenolsagen, nr. 1980).

31 Jydske Tidende den 29. jan. 1972.

32 Politibekendtgørelse af 27. april.

33 Sønderjyden 15. feb. 1972.

34 Jyllands-Posten den 22. jan. 1972

35 Jydske Tidende, Dannevirke, Sønderjyden den 29. jan. 1972.

36 Ibid. den. 1. marts 1972.

37 Ibid. den 2.-3. marts 1972.

38 Jydske Tidende, Sønderjyden den 3. marts 1972.

Dannevirke, Sønderjyden 13.-14. marts 1972

40 Dannevirke, Sønderjyden, Jydske Tidende 14.-15. marts 1972

41 Dannevirke, Jydske Tidende den 26. marts 1972.

42 Citeret i Dannevirke den 25. jan. 1972 43 Citeret i Sønderjyden den 25. jan. 1972. 44 Jydske Tidende den 26. jan. 1972.

\section{Zusammenfassung}

In der Nacht zwischen dem 20. und 21. Januar 1972 um etwa 23.30 verunglückte ein Tankwagen in dem kleinen Dorf Simmerstedt zehn Kilometer nordwestlich von Hadersleben in Nordschleswig. Hier drehte es sich an und für sich um einen banalen Unfall, die Umstände waren aber solcher Art, dass gerade dieser Unfall für die Umweltpolitik in Dänemark weitreichende Bedeutung bekam. Es war von dem ersten größeren Verunreinigungsunfall die Rede. In diesem Artikel wird es beschrieben, wie dieser Unfall sich zu einer riesigen Umweltkatastrophe entwickeln konnte. Der Focus richtet sich auf die unmittelbare Bereitschaft, aber auch auf die Folgen der Verunreinigung und auf die finanziellen und politischen Konsequenzen.
45 Jydske Tidende den 27. jan. 1972 46 Dannevirke den 10. feb. 1972.

Haderslev (RÅ̊, Haderslev Kriminalpoliti, Akter vedrørende fenolsagen, nr. 1978). 8 Rapport afgivet til Justitsministeriet over hændelsesforløbet i sagen, dateret
7. apr. 1972 (RA $\AA$, Haderslev Kriminalpoliti, Akter vedrørende fenolsagen, nr. 1980) samt notat om udgifterne i steriet nr. 810, journalsag 240-53" $)$.

50 Ibid.

Svarskrift fra Assurance-Compagni(RAK, Justitsministeriet nr. 810, journalsag 240-53"

52 Brev fra Kammeradvokaten til Justitsministeriet dateret 28. jan. 1974. (RAK, Justits-

53 Forligsteksten (RAK, Justitsministeriet nr. 810, journalsag 240-53"I) samt artikel i Hejmdal den 28. maj 1974 55 Dannevirke den 20. juni 1972.

56 Folketingstidende 1971-72, sp. 2483 f. 58 Folketingstidende 1971-72, sp. $5988 \mathrm{ff}$. samt $6453 \mathrm{ff}$

59 6826 ff. samt $7028 \mathrm{ff}$. For selve lovforsla-

73, sp. 3841-4026. forbindelse med Simmerstedulykken,

4 Udkast til forligstekst (RAK, Justits-

(1) 